\title{
Paracoccus carotinifaciens sp. nov., a new aerobic Gram-negative astaxanthin-producing bacterium
}

\author{
Akira Tsubokura, Hisashi Yoneda and Haruyoshi Mizuta
}

Central Technical Research Laboratory, Nippon Oil Company Ltd, 8 Chidori-cho, Naka-ku, Yokohama

231-0815, Japan
Author for correspondence: Akira Tsubokura. Tel: +81 456257171 . Fax: +81 456257298. e-mail: tsubokura.akira@nisseki.co.jp
Keywords: Paracoccus, Paracoccus carotinifaciens, Proteobacteria, carotenoid, astaxanthin

\section{INTRODUCTION}

Astaxanthin (3,3'-dihydroxy- $\beta, \beta$-carotene- $4,4^{\prime}$-dione) is a carotenoid widely distributed in nature and is present in marine animal tissues such as those of red sea bream, salmon and lobsters (Fujita et al., 1983; Johnson, 1991; Nelis \& De Leenheer, 1991). The following organisms have been reported to produce astaxanthin: the basidiomycetous yeast Phaffia rhodozyma (Miller et al., 1976), the green alga Haematococcus pluvialis (Bubrick, 1991), the Gram-positive bacterium Brevibacterium 103 (Iizuka \& Nishimura, 1969) and the Gram-negative marine bacterium Agrobacterium aurantiacum (Yokoyama et al., 1994). We screened many isolates which produced orange or red pigments from soil samples. As a result, we were able to isolate a strain capable of producing astaxanthin.

In this paper, we describe the results of a taxonomic and $16 \mathrm{~S}$ rDNA sequence analysis of the astaxanthinproducing strain. We concluded that this strain should be classified as a new species of the genus Paracoccus, and Paracoccus carotinifaciens sp. nov. is proposed for the strain, with type strain E-396 ${ }^{\mathrm{T}}$ (= IFO $\left.16121^{\mathrm{T}}\right)$.

The DDBJ/EMBUGenBank accession number for the 16S rRNA nucleotide sequence data in this paper is $A B 006899$.

\section{METHODS}

Bacterial strains. The orange-pigmented and astaxanthinproducing bacterial strain, E-396 $6^{\mathrm{T}}\left(=\right.$ IFO $\left.16121^{\mathrm{T}}\right)$, was isolated from soils collected in the Kanagawa Prefecture, Japan. This strain was isolated on nutrient agar medium (Eiken), and was maintained on the same medium by serial inoculation. The type strains of known species of the genus Paracoccus were maintained on BY agar medium (Katayama-Fujimura \& Kuraishi, 1980).

Phenotypic characteristics. A strain was grown on nutrient agar and was submitted to morphological and physiological characterization. Morphological observation and principal biochemical characterization by use of API 20E strips (bioMérieux) were carried out on the isolated strain. The temperature ranges for growth were determined by incubating cells for $10 \mathrm{~d}$ on plates of nutrient agar at the following temperatures: $4,10,25,28,33,37$ and $40^{\circ} \mathrm{C}$. The $\mathrm{pH}$ ranges for growth were determined by incubating cells in nutrient broth medium at $28^{\circ} \mathrm{C}$ for $10 \mathrm{~d}$ at the following $\mathrm{pH}$ : $3 \cdot 0,4 \cdot 0,5 \cdot 0,6 \cdot 0,7 \cdot 0,8 \cdot 0,9 \cdot 0,10 \cdot 0,11 \cdot 0$ and $12 \cdot 0$. Acid and gas production from carbohydrates was determined using a modification of the Hugh and Leifson medium (Hugh \& Leifson, 1953) containing $\left(1^{-1}\right) 2 \mathrm{~g}$ Bacto-tryptone (Difco), $5 \mathrm{~g} \mathrm{NaCl}, 1 \mathrm{~g}$ yeast extract (Difco), $0.3 \mathrm{~g} \mathrm{~K}_{2} \mathrm{HPO}_{4}, 80 \mathrm{mg}$ bromothymol blue, $2 \mathrm{~g}$ agar and $1 \%(\mathrm{w} / \mathrm{v})$ carbohydrate. The following compounds were tested: L-arabinose, $\mathrm{D}$ xylose, D-glucose, D-mannose, D-fructose, D-galactose, maltose, sucrose, lactose, trehalose, D-sorbitol, D-mannitol, inositol and glycerol. The ability to use inorganic nitrogen sources was examined using a medium containing $\left(1^{-1}\right) 10 \mathrm{~g}$ 
glucose, $1 \mathrm{~g} \mathrm{KH}_{2} \mathrm{PO}_{4}, 0.5 \mathrm{~g} \mathrm{MgSO}_{4} .7 \mathrm{H}_{2} \mathrm{O}, 0 \cdot 2 \mathrm{~g} \mathrm{KCl}, 0.01 \mathrm{~g}$ yeast extract (Difco) and 1-2 g inorganic nitrogen source. Growth was monitored by measuring turbidity after $7 \mathrm{~d}$ incubation at $28^{\circ} \mathrm{C}$ with shaking. Denitrification was determined by the growth and the formation of gas in a stab culture of nutrient agar containing $0 \cdot 1 \%(\mathrm{w} / \mathrm{v})$ agar. Formation of 3-ketolactose was examined by the method of Bernaerts \& De Ley (1963). Catalase activity was determined by the presence of bubbles in a $3 \%$ hydrogen peroxide solution (Takeuchi et al., 1996). Oxidase activity was determined by using oxidase testing paper (Nissui Seiyaku). Slime production was examined both on a medium containing glucose as a carbon source and a medium containing sucrose as described by Jordan (1984).

Chemotaxonomic characteristics. Quinones and fatty acids were analysed by the method described by Komagata \& Suzuki (1987). Bacteriochlorophyll formation was determined by examining the absorption spectra of extracted pigments as described by Trüper \& Pfennig (1981). Cells were prepared by cultivation in anaerobic conditions in light or under aerobic conditions. Sphingolipid formation was determined by the method of Kawahara et al. (1991). Production of carotenoids was examined by the following method. Carotenoids were extracted with $0.5 \mathrm{ml}$ dichloromethane/methanol $(4: 1)$, to which was added $0.5 \mathrm{ml} \mathrm{n}$ hexane. The pigment was loaded into HPLC columns (silica column: Wako-sil 5SIL-120, Wako Pure Chemical). The mobile phase was a mixture of $\mathrm{n}$-hexane/dichloromethane/ methanol $(10: 8: 1)$. Pigments were monitored by measuring the $A_{470}$. Astaxanthin was identified by using the standard solution of authentic astaxanthin.

Electron microscopy. Cultured cells were suspended in $0 \cdot 1 \mathrm{M}$ phosphate buffer ( $\mathrm{pH} 7 \cdot 2$ ). The cells were fixed with $2 \%$ glutaraldehyde, washed with $0.05 \mathrm{M}$ cacodylate buffer and postfixed with $1 \%$ osmium tetroxide. The fixed cells were dehydrated in ethanol, and the ethanol was replaced with propylene oxide before embedding in Epon resin and sectioning with an ultramicrotome. Sections were examined with a Philips EM420 transmission electron microscope.

DNA base composition and DNA-DNA hybridization. The $\mathrm{G}+\mathrm{C}$ content of the genomic DNA was determined by the method of Tamaoka \& Komagata (1984). DNA-DNA hybridizations were carried out by the photobiotin method using micro plates described by Ezaki et al. (1990).

Determination of the 165 rDNA sequence and phylogenetic analysis. The $16 \mathrm{~S}$ rDNA sequence for strain $\mathrm{E}-396^{\mathrm{T}}$ was determined by the cloning method according to Anzai $e$ t al. (1997). Phylogenetic analysis was carried out as described by Anzai et al. (1997). The determined sequence was compared with those of the $\alpha-2, \alpha-3$ Proteobacteria.

\section{RESULTS}

\section{Cell shape, Gram stain and motility}

Strain E-396 ${ }^{\mathrm{T}}$ was Gram-negative, motile by means of peritrichous flagella, rod-shaped and non-sporeforming. The cells were $0.3-0.75 \mu \mathrm{m}$ in diameter and $1 \cdot 0-5 \cdot 0 \mu \mathrm{m}$ in length (Fig. 1). The cells were elongated or swollen at the early stage of culture when the organisms were grown in a liquid medium containing yeast extract $(1 \%)$.

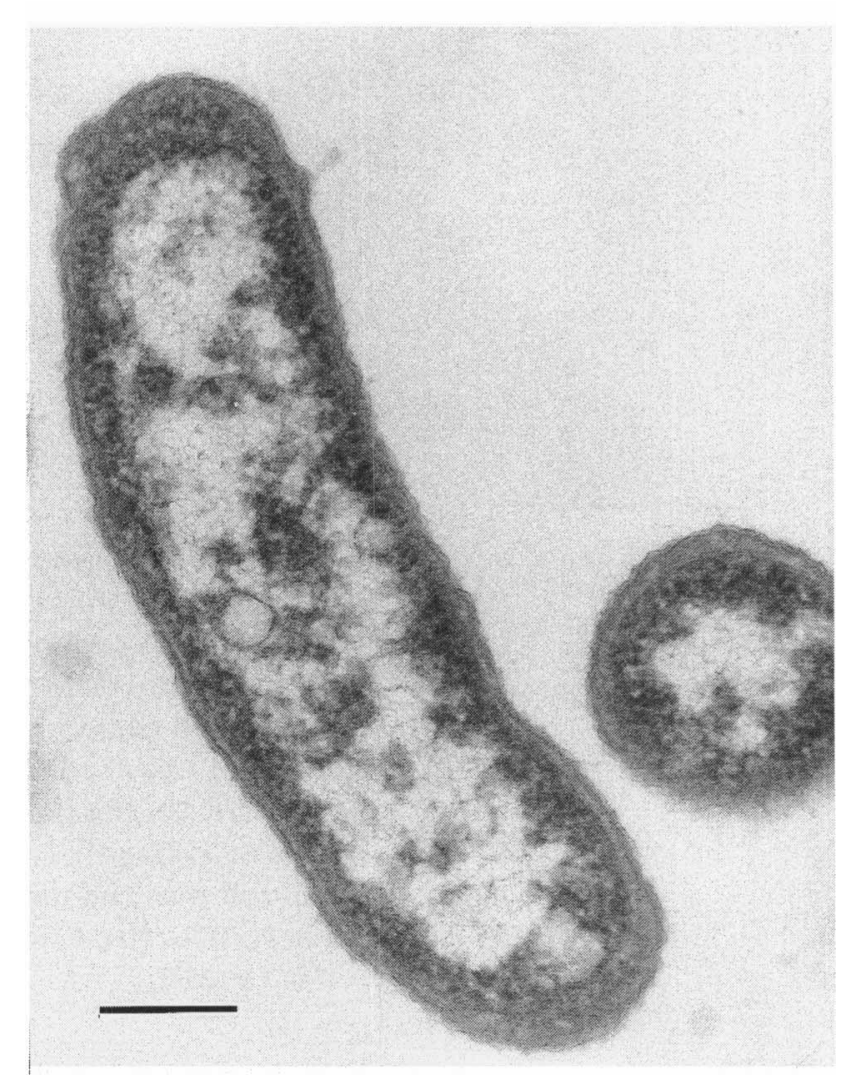

Fig. 1. Electron micrograph of a thin-sectioned cell of strain $\mathrm{E}-396^{\top}$ grown on nutrient agar for $24 \mathrm{~h}$ at $25^{\circ} \mathrm{C}$. Bar, $0.2 \mu \mathrm{m}$.

\section{Physiological characteristics}

On nutrient agar, this strain formed round, smooth, orange colonies. The physiological and chemotaxonomic characteristics of strain E-396 ${ }^{\mathrm{T}}$ are summarized in Table 1. Strain E-396 ${ }^{\mathrm{T}}$ was able to grow between 10 and $33^{\circ} \mathrm{C}$, with optimum growth at $28^{\circ} \mathrm{C}$, and the $\mathrm{pH}$ range for growth was $6 \cdot 0-9 \cdot 0$, with an optimum $\mathrm{pH}$ of $6 \cdot 5-7 \cdot 5$. Strain E-396 ${ }^{\mathrm{T}}$ utilized ammonium as a nitrogen source but did not utilize nitrate. Denitrification was not performed. 3-Ketolactose was not produced. This strain was catalase-positive, oxidase-positive and urease-negative. Gelatin and starch were not hydrolysed. This strain did not form slime on either glucose agar or sucrose agar.

\section{Chemotaxonomic characteristics}

The major isoprenoid quinone was ubiquinone- 10 . The major non-hydroxyl fatty acid was $\mathrm{C}_{18: 1}$, which constituted $82 \%$ of the total non-hydroxyl acids. 3Hydroxyl fatty acids were present, with $3-\mathrm{OH} \mathrm{C}_{10: 1}$ predominating. Sphingolipids were not produced. Because the strain was not able to grow anaerobically in light, the formation of bacteriochlorophyll was examined using cells cultured aerobically. This strain did not produce bacteriochlorophyll under aerobic conditions. The major carotenoid was astaxanthin; 
Table 1. Characteristics of strain E-396

\begin{tabular}{|c|c|}
\hline Character & Strain E-396 ${ }^{T}$ \\
\hline \multicolumn{2}{|l|}{ Morphological characters } \\
\hline Cell width $(\mu \mathrm{m})$ & $0.3-0 \cdot 75$ \\
\hline Cell length $(\mu \mathrm{m})$ & $1 \cdot 0-5 \cdot 0$ \\
\hline Polymorphism & + \\
\hline Motility & + \\
\hline Spores & - \\
\hline Optimum temp. for growth $\left({ }^{\circ} \mathrm{C}\right)$ & 28 \\
\hline Optimum $\mathrm{pH}$ for growth & 7 \\
\hline \multicolumn{2}{|l|}{ Utilization of: } \\
\hline D-Glucose & + \\
\hline L-Arabinose & - \\
\hline D-Mannose & + \\
\hline D-Mannitol & + \\
\hline $\mathrm{N}$-Acetyl-D-glucosamine & - \\
\hline Maltose & + \\
\hline Potassium gluconate & + \\
\hline n-Capric acid & - \\
\hline Adipic acid & - \\
\hline DL-Malic acid & + \\
\hline Sodium citrate & - \\
\hline Phenyl acetate & - \\
\hline Acid or gas production from: & Acid/gas \\
\hline L-Arabinose & $+1-$ \\
\hline D-Xylose & $+1-$ \\
\hline D-Glucose & $+1-$ \\
\hline D-Mannose & $+1-$ \\
\hline D-Fructose & $-1-$ \\
\hline D-Galactose & $+1-$ \\
\hline Maltose & $+/-$ \\
\hline Sucrose & $+/-$ \\
\hline Lactose & $+1-$ \\
\hline Trehalose & $+/-$ \\
\hline D-Sorbitol & $+/-$ \\
\hline D-Mannitol & $+1-$ \\
\hline Inositol & $-1-$ \\
\hline Glycerol & $+1-$ \\
\hline Nitrate reduction & - \\
\hline Denitrification & - \\
\hline \multicolumn{2}{|l|}{ Production of: } \\
\hline Urease & - \\
\hline Oxidase & + \\
\hline Catalase & + \\
\hline$\beta$-Galactosidase & + \\
\hline Arginine dihydrolase & - \\
\hline Pigment & $+($ orange to red $)$ \\
\hline lndole & - \\
\hline 3-Ketolactose & - \\
\hline Slime & - \\
\hline \multicolumn{2}{|l|}{ Hydrolysis of: } \\
\hline Aesculin & + \\
\hline Starch & - \\
\hline Gelatin & - \\
\hline \multicolumn{2}{|l|}{ Chemotaxonomic characteristics } \\
\hline Quinone system & Q-10 \\
\hline $\mathrm{G}+\mathrm{C}$ content $(\mathrm{mol} \%)$ & 67 \\
\hline Bacteriochlorophyll & - \\
\hline Sphingolipid & - \\
\hline \multicolumn{2}{|l|}{ Major fatty acids } \\
\hline Non-hydroxyl acids & $\mathrm{C}_{18: 1}$ \\
\hline 3-Hydroxyl fatty acids & $3-\mathrm{OH} \mathrm{C} 10: 0$ \\
\hline Major carotenoids & Astaxanthin \\
\hline
\end{tabular}

Table 2. Reassociation values (\%) between DNAs from strain E-396 and Paracoccus species

\begin{tabular}{|lc|}
\hline Organism & Strain E-396 $^{\mathbf{T}}$ \\
\hline Strain E-396 $^{\mathrm{T}}$ & 100 \\
Paracoccus aminophilus IAM 14245 $^{\mathrm{T}}$ & 23 \\
Paracoccus aminovorans IAM 14244 $^{\mathrm{T}}$ & 22 \\
Paracoccus denitrificans IAM 12479 $^{\mathrm{T}}$ & 21 \\
Paracoccus kocurii IAM 14243 $^{\mathrm{T}}$ & 26 \\
Paracoccus versutus IAM 12814 $^{\mathrm{T}}$ & 23 \\
\hline
\end{tabular}

other carotenoids were also detected. The $\mathrm{G}+\mathrm{C}$ content of the DNA of strain E-396 ${ }^{\mathrm{T}}$ was $67 \mathrm{~mol} \%$.

\section{DNA-DNA hybridizations}

The DNA-DNA reassociation among strain E-396 ${ }^{\mathrm{T}}$ and the genus Paracoccus species is shown in Table 2. The DNA-DNA binding values between strain E-396 ${ }^{\mathrm{T}}$ and five species of the genus Paracoccus are between 21 and $26 \%$.

\section{$16 S$ rRNA sequence and phylogenetic tree analysis}

Nearly full-length fragments of the 16S rDNA from strain E-396 ${ }^{\mathrm{T}}$ were amplified by PCR, and one of these fragments was sequenced. The phylogenetic positions of the new isolate within the $\alpha-3$ subclass of the Proteobacteria are shown in Fig. 2. Strain E-396 ${ }^{\mathrm{T}}$ was closely related to species belonging to the genus Paracoccus and formed a cluster with those species. The bootstrap value to the Paracoccus cluster including strain E-396 ${ }^{\mathrm{T}}$ from the other $\alpha-3$ Proteobacteria was $57 \%$. The sequence of strain E-396 ${ }^{\mathrm{T}}$ exhibited the highest levels of similarity to the sequences of Paracoccus alcaliphilus. The levels of similarity between the sequence of strain E-396 ${ }^{\mathrm{T}}$ and that of P. alcaliphilus, Paracoccus thiocyanatus and Paracoccus solventivorans, which were not subjected to DNA-DNA hybridization assay, were 95.9, 94.9 and $94.9 \%$, respectively.

\section{DISCUSSION}

In the present study, a strain of astaxanthin-producing bacteria was isolated. Phylogenetic analysis was carried out based on 16S rRNA gene sequence information for this strain, E-396 ${ }^{\mathrm{T}}$, and the analysis showed that the newly isolated astaxanthin-producing bacterium falls into the $\alpha-3$ subclass of the Proteobacteria and forms a cluster with the species of the genus Paracoccus. This implies that the new isolate should be classified as a member of the genus Paracoccus. At the time of writing the genus Paracoccus consisted of the following eight species: P. alcaliphilus (Urakami et al., 1989), Paracoccus aminophilus (Urakami et al., 1990), Paracoccus aminovorans (Urakami et al., 1990), Para- 


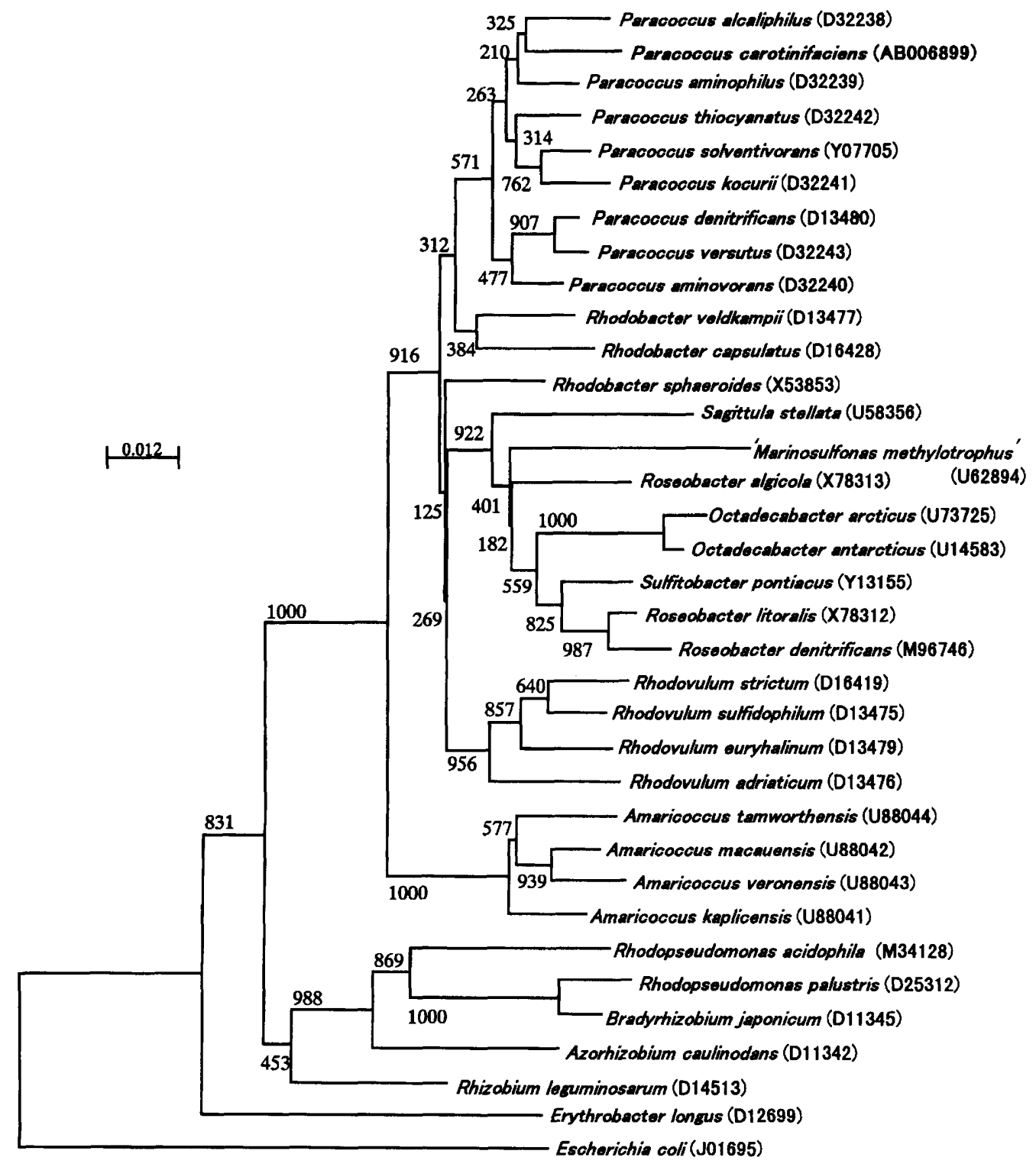

Fig. 2. Phylogenetic relationships among the species of the $\alpha-3$ Proteobacteria and representative species of the other $\alpha$ Proteobacteria. The tree was drawn by the neighbour-joining method, and the results of bootstrap analysis (1000 replications) are shown on each branch. Escherichia coli was used as the root organism. Accession numbers are in parentheses. Bar, $0.012 K_{\text {nuc- }}$

coccus denitrificans, Paracoccus kocurii (Ohara et al., 1990), P. solventivorans (Siller et al., 1996), P. thiocyanatus (Katayama et al., 1995) and Paracoccus versutus (Katayama et al., 1995) [two new species have been validated recently: Paracoccus alkenifer (Lipski et al., 1998) and Paracoccus marcusii (Harker et al., 1998)]. The DNA-DNA reassociation levels between strain E-396 ${ }^{\mathrm{T}}$ and five known Paracoccus species are sufficiently low to assure classification of the isolate as a new species of the genus Paracoccus. With regard to $P$. alcaliphilus, $P$. thiocyanatus and $P$. solventivorans, which were not subjected to DNA-DNA hybridization assay, the levels of similarity of their 16S rDNA sequences imply that strain E-396 $6^{\mathrm{T}}$ can be differentiated from these species genotypically. Our isolate can be distinguished from the known species of the genus Paracoccus by its phenotypic characteristics, including motility, pigment production, denitrification and urease activity (Table 3).

Photosynthetic bacterial genera Rhodobacter (Imhoff et al., 1984), Rhodovulum (Hiraishi \& Ueda, 1994) and Roseobacter (Shiba, 1991) contain carotenoids of the spheroidene series as photosynthetic pigments. In contrast, the newly isolated non-photosynthetic bacteria produce the polar carotenoid astaxanthin as a major pigment. An elucidation of the function of carotenoids produced by this strain has become a subject of considerable interest.

On the basis of its phenotypic and chemotaxonomic 
A new aerobic astaxanthin-producing bacterium

Table 3. Characteristics differentiating $P$. carotinifaciens from other species

\begin{tabular}{|c|c|c|c|c|}
\hline Strain & Motility & Colour of colonies* & Denitrification & Urease \\
\hline P. carotinifaciens & + & Orange to red & - & - \\
\hline$P$. alcaliphilus $\dagger$ & - & Creamy white & - & + \\
\hline P. aminophilus & - & Creamy white & - & - \\
\hline P. aminovorans $\ddagger$ & - & Creamy white & - & - \\
\hline P. denitrificans\$ & - & White & + & + \\
\hline P. kocuriiß & - & Creamy white & + & - \\
\hline$P$. solventivorans $\|$ & - & NA & + & NA \\
\hline P. thiocyanatus & - & Creamy white & + & - \\
\hline$P$. versutus & + or $-* *$ & Creamy white & + & - \\
\hline
\end{tabular}

NA, No data available.

* Data from this study. Colonies were grown on BY agar medium.

† Data from Urakami et al. (1989).

† Data from Urakami et al. (1990).

$\S$ Data from Ohara et al. (1990).

|| Data from Siller et al. (1996).

I Data from Katayama et al. (1995).

** There are positive and negative reports for motility (Katayama et al., 1995).

characteristics, 16S rDNA sequence analysis and DNA-DNA hybridization studies, we propose that strain E-396 ${ }^{\mathrm{T}}$ should be placed in a new species, Paracoccus carotinifaciens. A description of the new species is given below.

\section{Description of Paracoccus carotinifaciens sp. nov.}

Paracoccus carotinifaciens (ca.ro.ti.ni.fa'ci.ens. M.L. neut. n. carotinum carotene; L. part. adj. faciens making/producing; M.L. part. adj. carotinifaciens carotene/carotenoid-producing).

Gram-negative motile rods by means of peritrichous flagella. Not spore forming. Cells range from $0 \cdot 3$ to $1.0 \mu \mathrm{m}$ in diameter and 1.0 to $5.0 \mu \mathrm{m}$ in length. Cells are elongated or swollen at the early stage of culture when the organisms are grown in a liquid medium containing yeast extract $(1 \%)$. Colonies are circular and orange to red. The optimal growth temperature is between 25 and $30^{\circ} \mathrm{C}$. No growth occurs at $37^{\circ} \mathrm{C}$. Oxidase and catalase are positive. Urease is negative. Aerobic. Nitrate is not reduced. Denitrification is not performed. Non-phototrophic. Slime is not produced. Ubiquinone-10 is the major quinone. Bacteriochlorophyll is not produced. Capable of producing astaxanthin. The major cellular non-hydroxyl fatty acid is unsaturated $\mathrm{C}_{18: 1}$. The major hydroxyl fatty acid is 3$\mathrm{OH} \mathrm{C}_{10: 1}$. Utilizes D-glucose, D-mannose, D-mannitol, $D$-maltose, potassium gluconate and DL-malic acid. Acid production from L-arabinose, D-xylose, D-glucose, D-mannose, D-galactose, maltose, sucrose, lactose, trehalose, D-sorbitol, D-mannitol and glycerol. DNA G $+\mathrm{C}$ composition is $67 \mathrm{~mol} \%$. The type strain is IFO $16121^{\mathrm{T}}$.

\section{ACKNOWLEDGEMENTS}

We thank Hiroshi Kuraishi of the Japan Food Research Laboratories for his valuable advice. We also thank Hiroshi Oyaizu of the University of Tokyo for the 16S rRNA sequencing, phylogenetic analysis and DNA-DNA hybridization, and for his valuable advice.

\section{REFERENCES}

Anzai, Y., Kudo, Y. \& Oyaizu, H. (1997). The phylogeny of the genera Chryseomonas, Flavimonas, and Pseudomonas supports synonymy of these three genera. Int J Syst Bacteriol 47, 249-251.

Bernaerts, M. J. \& De Ley, J. (1963). A biochemical test for crown gall bacteria. Nature 197, 406-407.

Bubrick, P. (1991). Production of astaxanthin from Haematococcus. Bioresour Technol 38, 237-239.

Ezaki, T., Adnan, S. \& Miyake, M. (1990). The microplate hybridization method for determining taxonomic relations between bacterial species. Nippon Saikingaku Zasshi 45, 851857.

Fujita, T., Satake, M., Watanabe, T., Kitajima, C., Miki, W., Yamaguchi, K. \& Konosu, S. (1983). Pigmentation of cultured red sea bream with astaxanthin diester purified from krill oil. Nippon Suisan Gakkaishi 49, 1855-1865.

Harker, M., Hirschberg, J. \& Oren, A. (1998). Paracoccus marcusii sp. nov., an orange Gram-negative coccus. Int J Syst Bacteriol 48, 543-548.

Hiraishi, A. \& Ueda, Y. (1994). Intrageneric structure of the genus Rhodobacter: transfer of Rhodobacter sulfidophilus and related marine species to the genus Rhodovulum gen. nov. Int $J$ Syst Bacteriol 44, 15-23.

Hugh, R. \& Leifson, E. (1953). The taxonomic significance of fermentative versus oxidative metabolism of carbohydrates by various gram-negative bacteria. J Bacteriol 66, 24-26.

lizuka, H. \& Nishimura, Y. (1969). Microbiological studies on 
petroleum and natural gas. X. Carotenoid pigments of hydrocarbon-utilizing bacteria. J Gen Appl Microbiol 15, 127-134.

Imhoff, J. F., Trüper, H. G. \& Pfennig, N. (1984). Rearrangement of the species and genera of the phototrophic 'purple nonsulfur bacteria'. Int J Syst Bacteriol 34, 340-343.

Johnson, E. A. (1991). Astaxanthin from microbial sources. Crit Rev Biotechnol 11, 297-326.

Jordan, D. C. (1984). Family III. Rhizobiaceae Conn 1938, $321^{\mathrm{AL}}$. In Bergey's Manual of Systematic Bacteriology, vol. 1, pp. 234-256. Edited by N. R. Krieg \& J. G. Holt. Baltimore: Williams \& Wilkins.

Katayama-Fujimura, Y. \& Kuraishi, H. (1980). Characterization of Thiobacillus novellus and its thiosulfate oxidation. J Gen Appl Microbiol 26, 357-367.

Katayama, Y., Hiraishi, A. \& Kuraishi, H. (1995). Paracoccus thiocyanatus sp. nov., a new species of thiocyanate-utilizing facultative chemolithotroph, and transfer of Thiobacillus versutus to the genus Paracoccus versutus comb. nov. with emendation of the genus. Microbiology 141, 1469-1477.

Kawahara, K., Seydel, U., Matsuura, M., Danbara, H., Rietschel, E. Th. \& Zähringer, U. (1991). Chemical structure of glycosphingolipids isolated from Sphingomonas paucimobilis. FEBS Lett 292, 107-110.

Komagata, K. \& Suzuki, K. (1987). Lipid and cell-wall analysis in bacterial systematics. Methods Microbiol 19, 161-193.

Lipski, A., Reichert, K., Reuter, B., Sproer, C. \& Altendorf, K. (1998). Identification of bacterial isolates from biofilters as Paracoccus alkenifer sp. nov. and Paracoccus solventivorans with emended description of Paracoccus solventivorans. Int $J$ Syst Bacteriol 48, 529-536.

Miller, M. W., Yoneyama, M. \& Soneda, M. (1976). Phaffia, a new yeast genus in the Deuteromycotina (Blastomycetes). Int J Syst Bacteriol 26, 286-291.

Nelis, H. J. \& De Leenheer, A. P. (1991). Microbial sources of carotenoid pigments used in foods and feeds. $J$ Appl Bacteriol 70, 181-191.

Ohara, M., Katayama, Y., Tsuzaki, M., Nakamoto, S. \& Kuraishi, H. (1990). Paracoccus kocurii sp. nov., a tetramethylammoniumassimilating bacterium. Int J Syst Bacteriol 40, 292-296.

Shiba, T. (1991). Roseobacter litoralis gen. nov., sp. nov., and Roseobacter denitrificans sp. nov., aerobic pink-pigmented bacteria which contain bacteriochlorophyll a. Syst Appl Microbiol 14, 140-145.

Siller, H., Rainey, F. A., Stackebrandt, E. \& Winter, J. (1996). Isolation and characterization of a new gram-negative, acetonedegrading, nitrate-reducing bacterium from soil, Paracoccus solventivorans sp. nov. Int J Syst Bacteriol 46, 1125-1130.

Takeuchi, M., Weiss, N., Schumann, P. \& Yokota, A. (1996). Leucobacter komagatae gen. nov., sp. nov., a new aerobic grampositive, nonsporulating rod with 2,4-diaminobutyric acid in the cell wall. Int J Syst Bacteriol 46, 967-971.

Tamaoka, J. \& Komagata, K. (1984). Determination of DNA base composition by reversed-phase high-performance liquid chromatography. FEMS Microbiol Lett 25, 125-128.

Trüper, H. G. \& Pfennig, N. (1981). Characterization and identification of the anoxygenic phototrophic Bacteria. In The Prokaryotes, vol. 1, pp. 299-312. Edited by M. P. Starr, H. Stolp, H. G. Trüper, A. Balows \& H. G. Schlegel. New York: Springer.

Urakami, T., Tamaoka, J., Suzuki, K. \& Komagata, K. (1989). Paracoccus alcaliphilus sp. nov., an alkaliphilic and facultatively methylotrophic bacterium. Int J Syst Bacteriol 39, 116-121.

Urakami, T., Araki, H., Oyanagi, H., Suzuki, K. \& Komagata, K. (1990). Paracoccus aminophilus sp. nov. and Paracoccus aminovorans $\mathrm{sp}$. nov., which utilize $N, N$-dimethylformamide. Int $J$ Syst Bacteriol 40, 287-291.

Yokoyama, A., Izumida, H. \& Miki, W. (1994). Production of astaxanthin and 4-ketozeaxanthin by the marine bacterium, Agrobacterium aurantiacum. Biosci Biotechnol Biochem 58, $1842-1844$ 